History

The English landed on the Falkland Islands in 1690 , but the first settlement on this land off the coast of southem Argentina was not established until 1764 by the French. The next year, Britain established its own settlement and claimed the islands in the name of King George III. In 1766 , the Falklands were turned over to Spain, beginning a centurics-long territorial dispute, first between Britain and Spain, then between Britain and Argencina. The United Kingdom established a naval garrison on the islands in 1833, thus asserting its claim to them. In April 1982, Argentina invaded the islands, starting a two-month conflict that ended with the British regaining the capital and the Argentineans agreeing to a ccase-fire.

\section{Landmines/Uñ Oueruiew}

The 1982 conflict between Argentina and Britain resulted in thousands of AP and $A T$ mines being strewn across the islands, most of which were laid by Argentina, According to the Falklands' government, the islands contain over 16,000 mines in 101 minefields, covering a total of $20 \mathrm{sq} \mathrm{km}$. All of the minefields in the Falklands have been marked off and are well-labeled.

\section{Casualties}

The government of the Falkland Islands reports that "no civilian has been injured by mines or by unexploded ordnance to date." However, the U.S. State Department's 1998 publication Hidden Killers: The Global Landmine Crisis reported 14 casualtics had occurred up to that time. These were likely demining accidents, as it is reported that removal teans in 1983 suffered heavy casualties during their efforts. The 2004 Landmine Monitor states that no casualties were reported in 2002 or the first half of 2003 .

\section{Demining}

The United Kingdom, as a state party to the Ottawa Convention, is responsible for clearing the Falkl $₫$ nd's of mines by March 1, 2009. The United Kingdom is also party to Amended Protocol II of the Convention on Certain Conventional Weapons, which also obligates signatories to clear minefields in its tertitories. In October 2001, Argentina and the United Kingdom signed a Mcmorandum of Understanding, agreeing to share the costs of a feasibility study for mine clearance of the territory.

The Joint Working Party (JWP), a group of diplomats and experts from the United Kingdom and the Republic of Argentina formed to carry out a feasibility study on mine clearance in the Falklands, met October 26-27, 2004, in London. At the meeting, the JWP considered the goals of the feasibility study, such as the technical aspects, financial considerations and management responsibilities. The JWP will next meet in Buenos Aires during the second quarter of 2005 .

Clearance of mines in the Falklands is hampered by the weather and ground conditions; high winds, soft ground, and sand make detection and removal difficult. Thus far, over 4,000 mines and $2.8 \mathrm{mil}$ lion pieces of UXO have been removed. Becausc people are well aware of the location and dangers of the mines due to the markings and warning signs around the minefields and due to the fact that no recent mine incidents have occurred, the Falkland Islands government believes the removal of these minefields can wait. According to a statement issued to the Landmine Monitor, the government feels "there are other countries...that deserve priority over demining as many innocent people are killed regularly by unmarked mines."

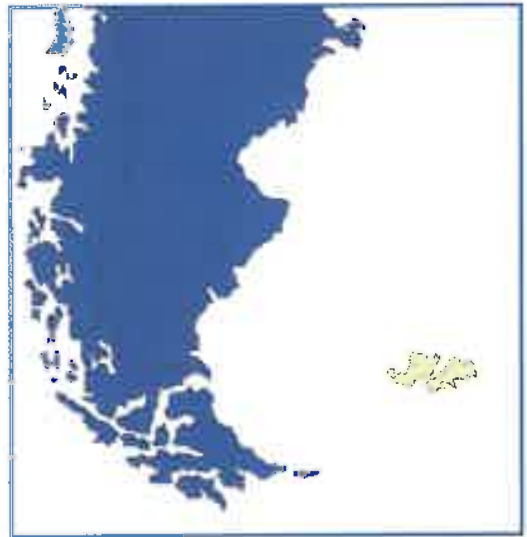

Realìin Check

Although the conflict is over in the Falklands, the remnants of war still remain. And while the threat of landmines is contained and well-matked, it is still not completely alleviated. There are some areas bordering the known mincfields where it is suspected that water that has entered the minefield may have shifted the locations of some mines.

The British government has another four years to clear the mines in the Falklands, according to its obligations under the Ottawa Convention. However, because Britain and Argentina agreed to share the financial burden of clearance in proportion to the number of mines laid by cach side, Argentina is responsible for the bulk of the cost. This could prove problemaric in light of Argentina's economic problcms in 2002 and 2003.

\section{Contact information}

\section{Charlene Rowland}

Falkland Islands Development Corp.

Stanley, Falkland Islands

Tel: +50027211

Fax: +50027210

E-mail: charlene@fidc.co.fk

Website: www.falklandislands.com 